\title{
Reading Strategies Training for College English Learners
}

\author{
Xinli Zhang \\ Foreign Language School \\ Huanghe Science and Technology College \\ Zhengzhou, China
}

\begin{abstract}
Learning strategies is the most decisive factor in learners' studying performance. Reading strategy is one of these learning strategies in studying process which has attracted more attention these years. Teachers need to change minds to involve students into new reading strategies training to improve students' interests in English reading.
\end{abstract}

Keywords—English; reading; learning; strategies; training

\section{INTRODUCTION}

This article will first introduce the current research on learning strategies, especially reading strategies for college students. Then it follows the effect of traditional teaching methods on reading strategies, and the content and steps of reading strategies training. The end of this article pays special attention on the suggestions when carrying out these reading strategies training steps.

\section{LEARNING STRATEGIES AND STRATEGY TRAINING}

Since 1970s of this century, people's interest in the Second Language Acquisition research have turned from the study of teaching methods to learners' variables study, people gradually realized the important factors of learners in second language learning. Among these factors, learning strategies is the most decisive one in learners' studying performance; Cohen defined 'learning strategies' as 'learning processes which are consciously selected by the learner. The element of choice is important here because this is what gives a strategy its special character. These are also moves which the learner is at least partially aware of, even if full attention is not being given to them' (Cohen, 1998); it also refers to a series of actions that the language learners taken, directly for their English language learning. These actions include a battery of learners' specific learning methods, such as mechanical memory or associative memory and other methods to English words when forgetting their meanings, the bottom up, top-down reading model used in the course of reading, or skimming, skipping and other skills used for different reading purposes, the formulation of goals; selection, evaluation and adjustment of strategies involved in the process of language learners' learning are also included in these actions.

Strategy training is a hot research topic in applied linguistics in the last 20 years. It is also called learners training or learners training methods, which refers to develop training and practice for foreign language learners' learning strategy.
Language learning is a very complex process; it involves many factors, such as the learners' personalities, ages, their prior learning experiences, knowledge and attitudes on language and language learning, so there is a big difference in and after the language learners' learning. However, some research shows that successful language learners have their common characteristics: they are active practitioners and users of those languages, they have a strong desire in language use; they not only pay attention to language forms, but also pay attention to the meanings of language; they can use their own language knowledge to monitor their language expression, to find and correct some errors; they have their own special learning strategies, when they meet some language points that they don't understand, except to do nothing about this, they try to guess meanings of these language points, try to solve the problems and study creatively through a variety of clues.

In recent years, reading strategy, one strategy in learning strategies, has attracted more and more people's attention. Reading strategy is the actions language learners take to solve these difficulties appearing in their reading process. It not only contains some reading skills, but also includes the readers' selective and controlled behaviors, in aims to achieve their expected reading purpose. With the deepening of these researches, the content of reading strategy has been constantly enrich, from the traditional simple reading act to today's active discourse strategies which has an important role on motivating background knowledge and helping understand the whole discourse. In college English class, teaching on English reading is still the traditional, non-communicative teaching methods, which can not meet the requirements of current curriculum development. Teachers need to change their minds; they need to train students some new reading strategies, in order to improve students' interests and capacities in reading.

\section{The EFFECT OF TRAditional TeAching Methods ON READING STRATEGIES}

The current college English teaching is still mainly based on the kind of knowledge-teaching, that is, classroom teaching is still largely based on the traditional non-communicative types of teaching methods such as spoon-feeding. In other words, in language reading class, most teachers are still use the way of bottom-up, from words to sentences, to explain and to analyze the text sentence by sentence, paragraph by paragraph, to undertake students the form of language input instead of 
guiding the students to participate in the reading process, or training students' reading skills in English language communicative activities. A survey shows that $87.2 \%$ teachers explain new words and grammar in the classroom regularly, and some teachers actually take up more than $80 \%$ of the time. In the classroom, what students need are not the ability to use their imagination to think creatively, but the ability to remember the language elements in isolation; what students have obtained is just a linguistic phenomenon, but not the whole discourse information; what students have been trained is their memorizing ability, that is how to interpret words and grammar, but not their reading ability about understanding language, such as skimming, skipping, fast reading and other reading skills.

However, in many college English classes, this kind of language teaching has always lasting from the beginning to the end of a class, it weaken or even completely replaced the other kind of reading class, which aims to train students' reading skills and reading strategies. The result of which would lead to students' poor reading ability, and their lack of reading strategies awareness. Most non-English majors are most in need of the kind of reading ability that effectively obtained from books; however, this kind of their needs have always been ignored in college English teaching, at least rarely be trained in purpose. "Reading" or "Intensive Reading" is the main college teaching types in English class, however, they are not good for students' English study, and will have a bad effect on students' reading habits. Take a reading comprehension for example, a text is not simply a pile of sentences, its meaning does not exist in the fragmented words or sentences, but exist in connected discourse, which is constrained in the context. In the discourse level, only when one take out its meaning, can he say that he has a true understanding of the whole text. The purpose of reading is to obtain some information; the task of reading class is to teach students how to stimulate background knowledge or schema in their mind, so as to organically link the context, the discourse and the language together, to get information much more fast and accurate(Meilin Yao, 2000).

Just as one reading through his mother tongue, his second language reading is also involved in four important factors: reading purposes, reading attitudes, reading texts and reading strategies. As sophomores who have certain vocabulary and grammar knowledge, in many cases, their reading barrier is not due to the lack of their language knowledge, but to their improper reading strategies. Some students even did not have awareness of reading strategies, not to mention choosing the best reading method according to different reading purpose and different reading texts. Students do not have the ability to assess or to monitor their reading process so as to adjust or select their reading strategies. Whichever kind of subject matter, or whichever genre of texts, they all use the word-byword, bottom-up approach to read. They are not according to their own situation to adjust their reading speed positively, but passively constrained in the reading speed. The reasons of this may be manifold, but the improper teaching strategies of reading is one of the most direct and important reason, which caused the students lacking of reading strategies, so that they just have low reading abilities. Therefore, it is believed that, as responsible teachers, they must change their traditional teaching philosophy to give students some training on reading strategies, so that the students could improve their own reading abilities.

\section{Main CONTENT AND StePS OF REAding StRategy TRAINING}

The premise of reading strategies teaching is to use effective strategies, the so-called effective reading strategies refers to the strategies that could help learners improve their reading comprehension and their reading speed. In a summary of overseas research, the reading strategies teaching can be generally divided into the following four steps:

\section{A. Preparation Stage}

The purpose of this stage is to encourage students to reflect on their own reading process and improve their awareness on strategies. Foreign language teachers can organize the students in the form of interviews, group discussion or the whole class discussion, and ask students to reflect on how they complete their reading task. When they use some useful strategy in their discussion, teachers should be affirmative to it, and then ask the students to recall how they have used the strategy to help their understanding. After this stage, teachers can help students identify the reading strategies they have used, diagnose their existing problems to make training a target, at the same time, students could see the importance and the value of reading strategies, so they can have a positive attitude to learn the strategies.

\section{B. Presentation Stage}

At this stage, teachers give specific explanation and demonstrate new reading strategies, so that the students have their initial perceptions. Teachers' explanation should include the definition of reading strategies (what), the significance or the value of reading strategies (why), the explanation of its various uses with examples (how) and the condition of using reading strategies (where and when). These are the necessary factors to develop students' cognitive awareness. In the presentation of reading strategies, teachers should combine with specific reading tasks, and use reading strategies systematically into the target text, so that students could learn the benefits of reading strategies clearly. In the process of the presentation, teachers could use native language to explain, so that they can make the students understand reading strategies much better.

\section{Drill Stage}

At this stage, teachers give real reading tasks and encourage students to practise and use reading strategies. Students should first follow the guidance of their teachers, and then they imitate the steps how the teachers use reading strategies to read and complete the tasks, at the same time, students should be aware to monitor their own reading process. After this, teachers can gradually encourage students to use the reading strategies independently into reading tasks, together with providing each student sufficient time and enough training opportunities. Teachers can also organize group reading activities, so that students can give a brief description about their thinking process to each other, they can share their 
explanation with each other about how they used their reading strategies to complete their tasks, and how they get the answer. By doing this, students can share their favorite reading strategies and solve their common difficulties with each other in the process of reading.

\section{Evaluation Stage}

Teachers give timely assessment according to the situation whether students complete their reading tasks and how they use the reading strategies. Ways of evaluation are various, such as the inquiries, discussions, students' feelings about using these strategies or a questionnaire and so on after students' practice. Teachers' assessment should include these aspects: after their training, whether students' ability of completing the reading task is enhanced, whether they have used the taught strategies, whether the frequency of using the reading strategies is increased, whether they use the reading strategies properly and so on. Besides, teachers should also give selfassessment on their own ways and methods of their reading strategies teaching, in order to adjust and improve their teaching strategies of reading. In addition, teachers should help students understand how to assess the results after they use the reading strategies, how to assess their own progress in the process of reading by using reading strategy. These selfassessments could help students develop their metacognitive awareness and improve their strategy training efficiency.

\section{ATtENTIONS On READING StRATEGY TRAINING}

Before giving students reading strategy training, teachers should make proper preparations about two questions: first, teachers should have a full understanding on reading strategies; second, teachers should have a right attitude on changing their roles. As Cohen said, 'growing tendency among language educators to view teachers not only as language instructors but also as learner trainers' (Cohen, 2012). There is no doubt that, the more teachers know about language reading strategies, the more capable they will be the role of trainers; teachers should be encouragers who help students learn the English language, rather than the traditional controllers or managers. Thus, some scholars as Weifen Hua, Dianzhi Liu and Limei Wang give such suggestions that teachers should pay special attention to the following specific issues in the process of students' reading strategies training:

\section{A. Choose the Appropriate Strategies According to Students' Different Cognitive Levels and Needs}

Before the reading strategies training, teachers should give full consideration on students' cognitive levels and students' needs to select appropriate strategies; teachers should not only consider students' foreign language reading level, but also should pay attention to the practicability of the reading strategies, then they can prioritize those strategies which can improve students' reading level and language learning efficiency.

\section{B. Make Students Know the Values and Objectives of the Reading Strategies Training Clearly}

Teachers should enable language learners fully understand the values of reading strategies use, the training principles, the objectives and expected results and so on. Teachers should also give a clear description on when, how and why use these strategies. Researches show that the more conscious the trainees be on the use of reading strategies that were deliberate designed in the training activities, the more likely they are going to remember these strategies, and will further consolidate and internalize these strategies through other reading materials to make reading strategies training more effective.

\section{Integrate the Reading Strategy Training Together with Daily Reading Teaching}

Strategy training should be combined with the reading teaching, and then become an important part of English curriculum. If teachers make students do reading strategy training isolate, students will inevitably feel dull, and then it is not easy for them to see the connection between reading strategies and reading comprehension. In this way, students will have negative emotions, which is not helpful for them to learn reading strategies. Reading strategy teaching should be together with normal language teaching tasks, goals and teaching materials. Teachers introduce and strengthen reading strategies systematically with teaching contents; while students clarify the important values of these strategies and then actively collaborate with their teachers to practice and consolidate the reading strategies in the process of completing the reading tasks.

\section{Teachers Should Change Their Roles as Soon as Possible}

Learners or students in reading strategies teaching classes are no longer the passive recipients in the traditional classes, but active and responsible participants in their own reading process. Accordingly, foreign language teachers should change their traditional roles of governor, manager and controller to be roles of supporter, researchers and partners who help students read effectively.

\section{REFERENCES}

[1] Cohen A.D. Strategies in Learning and Using a Second Language[M]. Beijing: Foreign Language Teaching and Research Press,2012.08, P6, P65.

[2] Weifen Hua. Opinion on Strategy Training for Foreign language Learners. [J].Foreign Language World,2002,(3)

[3] Dianzhi Liu. Learning Strategy Research [M].Beijing: People's Education Press, 1999.

[4] Dianzhi Liu,Xiting Huang. Overview of Learning Strategy Research [J]. Educational Research,2002,(2)

[5] Limei Wang. Learning Strategy and Reading Education. [J]. Journal of Foreign Economic and Trade University,1999,(3)

[6] Meilin Yao. Teaching and Research on the Current Trend of Foreign Language Learning Strategies.[J]. Journal of Beijing Normal University,2000,(5) 